participate alongside their peers as fully as possible.

Palliative surgery can give children with functional single ventricle a level of activity enabling them to take part in most childhood activities. Further study of this group of children after more major physiological correction, such as the Fontan operation, would be useful to objectively assess the improvement in quality of life achieved by such treatment.

The authors thank Dr Chris Patterson for statistical advice. We also thank Jayne Rogers, Colette Anderson, Karen Morrison, and Helen Long for technical assistance. Dr Casey held a research fellowship supported from trust funds of the Royal Belfast Hospital for Sick Children.

1 Manning JA. Insurabílity and employability of young cardiac patients. In: Engle MA, ed. Pediatric cardiovascular disease. Philadelphia: Davis, 1980: 117-27.

$2 \mathrm{Oku} \mathrm{H}$, Shirotani H, Sunakara A, et al. Postoperative longterm results in total correction of tetralogy of Fallot, term results in total correction of tetralogy of Fallot, 1986; 41: 413-8.

3 Report of the New England regional infant cardiac program. Pediatrics 1980; 63 (No 2 suppl): 392-403.

4 Keith JD, Rowe RD, Vlad P. Heart disease in infancy and childhood. New York: Macmillan, 1978: 536.

5 Dick M, Fyler DC, Nadas AS. Tricuspid atresia: the clinica course in 101 patients. Am 7 Cardiol 1975; 36: 327-37.
6 Trusler GA, Williams WG. Long term results of shunt procedures for tricuspid atresia. Ann Thorac Surg 1980, 29: 312-6.

7 Bowyer JJ, Busst CM, Till JA, Lincoln C, Shinebourne EA. Exercise ability after Mustard's operation. Arch Dis Child 1990; 65: 865-70

8 Bruce RA, Kusumi F, Hosmer D. Maximal oxygen intake and nomographic assessment of functional aerobic impairment in cardiovascular disease. Am Heart $\mathcal{F} 1973$ 85: 546-62.

9 Fontan F, Baudet E. Surgical repair of tricuspid atresia. Thorax 1971; 26: 240-8.

10 Cullen S, Celermajer DS, Deanfield JE. Exercise in congenital heart disease. Cardiology in the Young 1991; 1: 129-35.

11 Godfrey S. Exercise and pulmonary function. In: Anderson RH, Macartney FJ, Shinebourne EA, Tynan M, eds. Paediatric cardiology. Edinburgh: Churchill Livingstone, 1987: 395-417.

12 Crawford DW, Simpson E, McIlroy MB. Cardiopulmonary function in Fallot's tetralogy after palliative shunting operations. Am Heart f 1967; 74: 463-72.

13 Warnes CA, Somerville J. Tricuspid atresia in adolescents and adults: current state and late complications. $\mathrm{Br}$ Hear f 1986; 56: 535-43.

14 Gewilly MH, Lundstrom UR, Bull C, Wyse RKH, Deanfield JE. Exercise responses in patients with congenital heart disease after Fontan repair: patterns and determinants of performance. $\mathfrak{f} \mathrm{Am}$ Coll Cardiol 1990; 6: 1424-32.

15 Driscoll DJ, Staats BA, Heise CT, et al. Functional single ventricle: cardiorespiratory response to exercise. $\mathcal{F ~} \mathrm{Am} \mathrm{Coll}$ Cardiol 1984; 4: 337-42.

16 Feldt RH, Strickler GB, Weidman WH. Growth of children with congenital heart disease. Am $\mathcal{f}$ Dis Child 1969; 117 573-9.

\title{
Screening for coeliac disease
}

How many papers in the next six years are going to have 'the year $2000^{\prime}$ in the title? I suspect that editors will soon have to start deleting the phrase unless it is strictly relevant. A report in the Lancet with the title 'Coeliac disease in the year 2000: exploring the iceberg' (C Catassi and colleagues, 1994; 343: 200-3), describes research performed in Italy in 1992 and 1993. Blood was obtained by finger prick from 3351 schoolchildren aged 11-15 years. These samples were tested for IgG and IgA antigliadin antibodies. Seventy one showed raised concentrations of both or either and those children were recalled for further testing. This time venous blood was taken and the antigliadin antibody tests were repeated together with a test for antiendomysium antibodies and serum immunoglobulins. Eighteen children were selected for jejunal biopsy on the basis of one or more of: raised IgA antigliadin antibodies, positive test for antiendomysium antibodies, or raised IgG antigliadin antibodies with selective IgA deficiency. Eleven of the 18 biopsies showed the changes of coeliac disease. These children were treated with a gluten-free diet and repeat biopsies on all 11 showed histological improvement. Six of the 11 had had recurrent aphthous stomatitis and most experienced increased well being or accelerated growth on a gluten-free diet.

Malignant disease, especially non-Hodgkin's lymphoma and cancers of mouth, pharynx, or oesophagus, is about twice as common in people with coeliac disease as in the general population and a strict gluten-free diet probably reduces the risk. ${ }^{1}$ This is the main argument in favour of screening and early treatment. The authors of this paper do not discuss the question of cost but the antibody tests are said to be expensive. Exactly how much illness could be prevented by this kind of screening is unknown. More information about costs and benefits is needed before widespread population screening is considered. 